\title{
ANEMIA PADA ANAK PRE-SCHOOL DAN HUBUNGANNYA DENGAN KECERDASAN DAN KESEHATAN (SYSTEMATIC REVIEW)
}

\author{
OLEH : \\ Saida 1, Asih Setiarini 2 \\ Program Studi Ilmu Kesehatan Masyarakat Departemen Gizi Kesmas UI \\ Email: nofelsaida@gmail.com
}

\section{A. ABSTRAK}

Anemia adalah masalah kesehatan global dan banyak terjadi pada anak-anak terutama di negara berkembang. Sudah diketahui bahwa anemia banyak berhubungan dengan pertumbuhan dan kekebalan tubuh seseorang. Studi literatur ini menggunakan pencarian via ProQuest dalam kurun waktu 12 bulan terakhir. Hasil studi ini bahwa anemia berhubungan dengan kinerja kognitif, resiko terjadinya ISPA dan GE serta stunting. Sosio Ekonomi dan pendidikan orang sangat berpengaruh terhadap asupan nutrisi anak, nutrisi yang baik dapat mencegah defisiensi mikronutrien terutama besi.

Anemia pada usia dini berkontribusi pada suplai oksigen ke otak, kekebalan tubuh serta pertumbuhan dan pekembangan anak yang menyebabkan kesulitan berkonsentrasi, rentan terhadap penyakit dan keterlambatan pertumbuhan, Perbaikan sosio ekonomi dan meningkatkan pendidikan orang tua diperlukan untuk meningkatkan status kesehatan dan gizi anak secara umum.

Kata kunci: Anemia, Negara Berkembang, Anak

(Jayaweera et al., 2019; Murtaza et al., 2019; Rahman et al., 2019)

\section{B. LATAR BELAKANG}

Anemia dapat terjadi pada setiap kelompok umur, namun anak-anak dan wanita usia subur lebih berisiko. Menurut WHO setidaknya ada $43 \%$ anak dibawah 5 tahun yang menderita anemia pada tahun 2011. Prevalensi anemia pada balita di Indonesia tergolong moderate, berkisar anatara $20-40 \%$. Anemia adalah masalah kesehatan masyarakat yang sering terjadi terutama di negara berkembang (WHO, 2015)

Secara umum anemia pada balita disebabkan oleh faktor asupan besi yang kurang, pola makan, pendidikan orang tua, status pekerjaan orang tua dan sosiodemografi (Rahman et al., 2019). Penyebab paling umum anemia pada anak adalah karena defisiensi besi (Kassebaum et al., 2015).
Pada bayi dan anak-anak anemia kronis dapat menyebabkan pertumbuhan yang tertunda dan efek jangka panjang pada perkembangan saraf dan perilaku, perubahan neurotransmitter, gangguan fungsi hipokampus, metabolisme energi, gangguan perkembangan kognitif, motorik, dan sosial-emosional. Keterlambatan pertumbuhan dan pubertas juga salah satu efek dari thalasemia (Lozoff, 2007; Perez et al., 2018; Shafir et al., 2006; Waugh et al., 2007)

Selain itu anemia dapat dikaitkan dengan penurunan saturasi oksihemoglobin, anemia dikaitkan dengan penurunan saturasi oksigen dari suplai darah ke otak yang diyakini menyebabkan infark serebral dan jika didiamkan, di masa depan berisiko stroke (Hogan et al., 2006). Banyak studi dilakukan untuk mengetahui akibat anemia pada anak. Studi litereatur ini bertujuan untuk 
menggambarkan akibat jangka panjang anemia pada usia dini.

\section{METODOLOGI PENELITIAN}

Penelitian ini merupakan literature review dari hasil penelitian di beberapa negara berkembang terkait dengan anemia pada anak pre-school dan hubunganya terhadap kecerdasan dan kesehatan anak. Sumber pencarian jurnal melalui ProQuest dalam kurun waktu 12 bulan terakhir. Jurnal yang terpilih sesuai kriteria inklusi berjumlah 3 jurnal

\section{HASIL PENELITIAN}

Literature review ini menjelaskan tentang anak preschool yang anemia dan hubunganya terhadap kecerdasan dan kesehatan.

\begin{tabular}{|c|c|c|c|c|}
\hline Penulis, Judul dan Tahun & Negara & Tujuan & Metode & Kesimpulan \\
\hline $\begin{array}{l}\text { Siti Fatihah Murtaza, } \\
\text { dkk. } 2019 . \\
\text { Sociodemographic, } \\
\text { nutritional, and cognitive } \\
\text { environmental factors } \\
\text { are associated with } \\
\text { performance among } \\
\text { Orang Asli children } \\
\text { in Malaysia }\end{array}$ & Malaysia & $\begin{array}{l}\text { Penelitian ini } \\
\text { dilakukan untuk } \\
\text { melihat hubungan } \\
\text { antara } \\
\text { sosiodemografi, faktor } \\
\text { nutrisi (BMI dan Hb) } \\
\text { dan faktor lingkungan } \\
\text { dengan kinerja } \\
\text { kognitif pada anak } \\
\text { berumur 2-6 tahun di } \\
\text { Malaysia. }\end{array}$ & $\begin{array}{l}\text { Penelitian ini } \\
\text { dilakukan dengan } \\
\text { metode cross- } \\
\text { sectional. Kinerja } \\
\text { kognitif dilakukan } \\
\text { dengan } \\
\text { menggunakan } \\
\text { metode The } \\
\text { Wechsler Preschool } \\
\text { and Primary Scale } \\
\text { of Intelligence, } \\
\text { Fourth Edition } \\
\text { (WPPSI-IV): } \\
\text { working memory } \\
\text { index (WMI), } \\
\text { processing speed } \\
\text { index (PSI), } \\
\text { dan cognitive } \\
\text { proficiency index } \\
\text { (CPI) pada anak } \\
\text { diatas } 4 \text { tahun. WMI } \\
\text { hanya digunakan } \\
\text { pada anak dibawah } \\
4 \text { tahun. } \\
\text { Tes Hb } \\
\text { menggunakan three } \\
\text { angled laser light } \\
\text { scatter method }\end{array}$ & $\begin{array}{l}\text { Kadar Hb } \\
\text { berhubungan } \\
\text { dengan } \\
\text { kecepatan } \\
\text { pemrosesan } \\
\text { dan } \\
\text { kemampuan } \\
\text { kognitif (PSI } \\
\text { dan CPI) } \\
\text { Kadar Hb } \\
\text { tidak } \\
\text { berhubungan } \\
\text { dengan } \\
\text { WMI } \\
\text { Faktor yang } \\
\text { paling } \\
\text { berpengaruh } \\
\text { terhadap } \\
\text { kinerja } \\
\text { kognitif } \\
\text { anak adalah } \\
\text { status } \\
\text { pendidikan } \\
\text { ayah, } \\
\text { pendapatan } \\
\text { ayah }\end{array}$ \\
\hline
\end{tabular}




\begin{tabular}{|c|c|c|c|c|}
\hline $\begin{array}{l}\text { Penulis, Judul dan } \\
\text { Tahun }\end{array}$ & Negara & Tujuan & Metode & Kesimpulan \\
\hline $\begin{array}{l}\text { M. Shafiqur } \\
\text { RahmanID, dkk. } 2019 . \\
\text { Association between } \\
\text { malnutrition and } \\
\text { anemia in under-five } \\
\text { children and women } \\
\text { of reproductive age: } \\
\text { Evidence from } \\
\text { Bangladesh } \\
\text { Demographic and } \\
\text { Health Survey } 2011\end{array}$ & Bangladesh & $\begin{array}{l}\text { Penelitian ini } \\
\text { dilakukan } \\
\text { untuk melihat } \\
\text { hubungan } \\
\text { antara } \\
\text { malnutrisi dan } \\
\text { anemia pada } \\
\text { anak dibawah } \\
5 \text { tahun dan } \\
\text { WUS. }\end{array}$ & $\begin{array}{l}\text { Penelitian ini } \\
\text { dilakukan dengan } \\
\text { studi cross- } \\
\text { sectional } \\
\text { berdasarkan desain } \\
\text { stratified cluster } \\
\text { sampling dua tahap } \\
\text { Data diambil dari } \\
\text { Bangladesh } \\
\text { Demographic and } \\
\text { Health Survey } \\
\text { (BDHS) tahun } \\
\text { 2011 tentang BMI, } \\
\text { status anemia dan } \\
\text { stunting } \\
\text { Status anemia pada } \\
\text { anak berumur 6-59 } \\
\text { bulan diambil } \\
\text { dengan } \\
\text { menggunakan alat } \\
\text { HemoCue }\end{array}$ & $\begin{array}{l}\text { Dalam penelitian ini } \\
\text { didapat bahwa } \\
\text { prevalensi anemia } \\
\text { lebih banyak pada } \\
\text { anak yang stunting } \\
\text { dibanding anak yang } \\
\text { tidak stunting. } \\
\text { Terdapat hubungan } \\
\text { yang signifikan } \\
\text { antara stunting dan } \\
\text { anemia } \\
\text { Maternal anemia } \\
\text { secara signifikan } \\
\text { menaikan risiko } \\
\text { anemia anak, karena } \\
\text { ada kesamaan pola } \\
\text { diet, lingkungan dan } \\
\text { sosiodemografi } \\
\text { antara keduanya }\end{array}$ \\
\hline
\end{tabular}

\begin{tabular}{|c|c|c|c|c|}
\hline $\begin{array}{l}\text { Penulis, Judul dan } \\
\text { Tahun }\end{array}$ & Negara & Tujuan & Metode & Kesimpulan \\
\hline $\begin{array}{l}\text { Jayaweera Arachchige } \\
\text { Asela Sampath } \\
\text { Jayaweera, Mohammed } \\
\text { Reyes dan Anpalaham } \\
\text { Joseph. } 2019 \text {. } \\
\text { Childhood iron } \\
\text { deficiency anemia leads } \\
\text { to recurrent respiratory } \\
\text { tract infections and } \\
\text { gastroenteritis. }\end{array}$ & $\begin{array}{l}\text { Sri } \\
\text { Lanka }\end{array}$ & $\begin{array}{l}\text { Penelitian ini } \\
\text { dilakukan untuk } \\
\text { melihat hubungan } \\
\text { antara anemia dan } \\
\text { kemungkinan } \\
\text { terjadinya infeksi } \\
\text { saluran pernapasan } \\
\text { akut (ISPA), infeksi } \\
\text { saluran kemih (ISK) } \\
\text { dan gastroenteritis } \\
\text { (GE) }\end{array}$ & $\begin{array}{l}\text { Penelitian ini } \\
\text { adalah studi case- } \\
\text { control dilakukan } \\
\text { pada anak berumur } \\
\text { 2-5 tahun di rumah } \\
\text { sakit } \\
\text { Anuradhapura. }\end{array}$ & $\begin{array}{l}\text { Anemia adalah } \\
\text { faktor risiko } \\
\text { terjadinya ISPA } \\
\text { dan GE dengan } \\
\text { OR masing- } \\
\text { masing } 3.08 \text { dan } \\
2,98 \\
\text { Anemia tidak } \\
\text { berhubungan } \\
\text { dengan ISK } \\
\text { Angka ISPA dan } \\
\text { GE berkurang } \\
\text { pada anak yang } \\
\text { diberi suplemen } \\
\text { besi selama } 3 \\
\text { bulan. }\end{array}$ \\
\hline
\end{tabular}




\section{E. PEMBAHASAN}

Dalam keadaan normal, bayi baru lahir memiliki cadangan zat besi yang cukup untuk bertahan hingga sekitar 6 bulan. Peningkatan berat badan yang signifikan selama tahun pertama kehidupan menyebabkan kenaikan kebutuhan zat besi untuk memenuhi produksi hemoglobin yang memadai. kebutuhan zat besi pada bayi 0-6 bulan sekitar $0,27 \mathrm{mg} /$ hari, 7-12 bulan sekitar $11 \mathrm{mg} /$ hari dan balita 1-3 tahun $7 \mathrm{mg} /$ hari. Untuk bayi dan balita yang kurang asupan zat besi dianjurkan untuk mengonsumsi zat besi dari suplemen (Baker et al., 2010; Faleiros et al., 2016).

Tannin, produk poli-fenol polimerasi, kalsium, zinc dan mangan dapat mengganggu penyerapan zat besi. Zat ini dapat ditemukan di the, kopi, cokelat, jagung dan susu. Fruktosa, sorbitol, vitamin $\mathrm{C}$, gula, daging, ikan dapat membantu penyerapan zat besi (Gropper, Sareen S. Smith, 2013).

Untuk mencegah terjadinya defisiensi zat besi pada awal kehidupan atau tidak mendapat sumber yang adekuat maka perlu diberikan suplementasi pada bayi usia 4 atau 6 bulan dengan dosis $1 \mathrm{mg} / \mathrm{kg} /$ hari. Untuk balita diberikan suplemen dengan dosis $2 \mathrm{mg} / \mathrm{kg} / \mathrm{hari}$. Pemberian suplemen sebaiknya dilakukan tidak bersamaan dengan konsumsi zat penghambat penyerapan zat besi dan mengurangi mual efek samping yang di timbulkan (Gropper, Sareen S. Smith, 2013; Pusponegoro, 2012).

\section{- Anemia dan status sosio-ekonomi}

Status sosio ekonomi keluarga sangat berpengaruh terhadap status kesehatan keluarga tersebut. Hal ini dipengaruhi dari kemampuan daya beli dan kualitas makanan yang tidak adekuat. Selain itu, sosio ekonomi berhubungan dengan tingkat pendidikan yang berhubungan terhadap praktik pemberian makan, ibu yang berpendidikan rendah cendenrung tidak sadar bahwa anaknya anemia dan tidak berusaha untuk mengatasinya (Islam, 2020; Murtaza et al., 2019).
Bayi dari keluarga dengan status sosio ekonomi rendah memiliki risiko 3 kali lebih tinggi untuk anemia disbanding bayi dari keluarga sosio ekonomi tinggi. Balita dari keluarga berstatus ekonomi rendah juga lebih rentan terhadap enemia (Islam, 2020). Penelitian Rahman 2019 menyatakan bahwa perbaikan status sosio ekonomi dapat menurunkan risiko anemia pada anak.

Pencegehan anemia di keluarga berstatus sosio ekonomi rendah bisa dengan mengonsumsi makanan kaya zat besi seperti hati sapi, tiram, daging, ikan, unggas, kacang-kacangan, tahu dan produk susu. Namun hal ini lebih banyak diketahui oleh orang dengan pendidikan yang cukup tinggi (Gropper, Sareen S. Smith, 2013).

\section{- Anemia dengan stunting}

Dalam penelitian Shafiqur 2019 meneliti hubungan antara anemia dan stunting pada anak usia 6-59 bulan. Secara umum prevalensi anemia sangat tinggi pada anak anak yang pendek dibandingkan dengan anak yang normal. Terdapat hubungan yang signifikan antara stunting dan anemia (Rahman et al., 2019).

Hasil penelitian didapat bahwa prevalensi anemia lebih banyak pada anak yang pendek dibandingkan dengan anak-anak yang tidak pendek. Risiko anemia menurun dengan bertambahnya usia, namun risiko penurunan ini lebih rendah pada anak yang pendek.

Anemia pada anak juga sangat berhubungan dengan maternal anemia, karena ada faktor-faktor tertentu yang sama yang saling mempengaruhi keduanya. Contohnya ibu dan anak memiliki akses terhadap makanan, pola makan, lingkungan hidup, pelayanan kesehatan dan faktor genetik yang sama (Khan et al., 2016; Mohammed et al., 2019).

Penelitian Shafigur menyatakan adanya hubungan yang cukup signifikan antara stunting dan anemia pada anak, hal ini bisa disebabkan langsung karena anemia atau hal-hal yang menyangkut anemia. Kekurangan nutrisi memang tidak secara langsung berkaitan dengan 
anemia, namun hal ini mengarah pada perubahan tertentu dalam tubuh yang membuat seorang anak rentan terhadap sakit yang dapat menyebabkan anemia. Satu studi menunjukkan anak perempuan yang menderita kekurangan gizi cenderung memiliki kekebalan tubuh yang lebih lemah yang membuatnya rentan terhadap penyakit (Khanam et al., 2011; Rahman et al., 2019).

\section{- Anemia dengan ISPA, ISK dan GE}

Anak dengan anemia memiliki kadar zat besi dan IL-6 yang jauh lebih rendah dibanding anak yang tidak anemia. IL (interleukin) 6 adalah sitokin yang disekresikan sel $\mathrm{T}$ dan makrofag untuk merangasang respon kekebalan tubuh selama infeksi (Hassan et al., 2016).

Anak-anak terutama berusia 6-59 bulan rentan terhadap penyakit ISPA, ISK dan GE. Hal ini dapat diasosiasikan terhadap lemahnya sistem kekebalan tubuh, yang salah satunya disebabkan oleh anemia (Hoberman et al., 1994; Rahman et al., 2019).

Cakupan zat gizi yang memadai dalam tubuh penting untuk proliferasi dan kematangan sel imun, terutama limfosit, sebagai respon terhadap infeksi (Soyano A \& Gómez M., 1999). Konsumsi suplemen besi dapat mengurangi risiko penyakit infeksi.

\section{- Anemia dengan kognitif}

Anak-anak yang anemia mudah lelah dan cenderung lebih ragu-ragu dalam bersikap, kurang ceria, kurang perhatian dan kurang mau menjelajahi lingkungan. Al-Mekhlafi dan murtaza menemukan bahwa kadar $\mathrm{Hb}$ berkontribusi terhadap kecepatan anak dalam memproses dan kecakapan kognitif (AlMekhlafi et al., 2011; Murtaza et al., 2019; Ngure et al., 2014). Studi yang dilakukan di China didapat bahwa kadar $\mathrm{Hb}$ yang rendah berhubungan signifikan dengan skor IQ(Ai et al., 2012)

Penelitian Murtaza menyatakan bahwa pendidikan ayah, pendapatan ayah, kadar $\mathrm{Hb}$, infeksi parasit, lingkungan rumah khususnya ketersediaan alat belajar, respon orang tua terhadap anak dan stimulasi berkaitan dengan kinerja kognitif anak. Hal ini menunjukkan bahwa anemia bukan satu-satunya faktor yang berkontribusi dalam kinerja kognitif anak, karena ada banyak faktor yang berkontribusi dalam perkembangan kognitif anak (Murtaza et al., 2019).

Perlunya dilakukan edukasi pada keluarga, khususnya ibu, untuk menaikan status kesehatan, status gizi anak dan mendorong stimulasi kognitif pada anak diperlukan untuk menaikan kinerja kokgnitif anak.

\section{F. SIMPULAN DAN SARAN}

Anemia adalah salah satu defisiensi mikronutrien yang berkontribusi pada kekebalan tubuh, pertumbuhan dan asupan oksigen ke otak. Oleh karena itu anemia mengakibatkan terhambatnya pertumbuhan anak, stunting, tidak optimal kinerja kognitif, rentan terkena penyakit.

Faktor yang sebenarnya paling berkontribusi dalam pencegahan anemia maupun defisiensi mikronutrien adalah sosiodemografi dan pendidikan orang tua. Sosiodemografi yang lebih berhubungan dengan status kesehatan yang lebih baik juga sedangkan pendidikan orang tua berhubungan dengan pola asuh dan pola pemberian makan pada anak.

Bedasarkan hasil pembahasan literatur yang sudah dilakukan mengenai efek buruk jangka Panjang anemia pada usia dini maka disarankan bagi orang tua dengan anak yang anemia untuk mengonsumsi suplemen zat besi berdosis $1 \mathrm{mg}$. konsumsi suplemen sebaiknya dilakukan bersamaan dengan vitamin $\mathrm{C}$ dilakukan sebelum tidur.

Selain itu diperlukan adanya edukasi nutrisi pada ibu-ibu tentang kecukupan nutrisi harian bagi anak. Edukasi makanan harian yang kaya nutrien dan murah diperlukan bagi keluarga, terutama ibu rumah tangga,. Hati sapi, tiram, tahu dan susu mengandung zat besi yang tinggi dengan harga cukup terjangkau.

\section{G. REFRENSI}

Ai, Y., Zhao, S. R., Zhou, G., Ma, X., \& Liu, J. (2012). Hemoglobin status associated with performance IQ but not verbal IQ in 
Chinese preschool children. Pediatrics International, 54(5), 669-675. https://doi.org/10.1111/j.1442200X.2012.03648.x

Al-Mekhlafi, H. M., Mahdy, M. A., Sallam, A. A., Ariffin, W. A., Al-Mekhlafi, A. M., Amran, A. A., \& Surin, J. (2011). Nutritional and socio-economic determinants of cognitive function and educational achievement of Aboriginal schoolchildren in rural Malaysia. British Journal of Nutrition, 106(7), 1100-1106. https://doi.org/10.1017/S00071145110014 49

Hoberman, A., Wald, E. R., Reynolds, E. A., Penchansky, L., \& Charron, M. (1994). Pyuria and bacteriuria in urine specimens obtained by catheter from young children with fever. The Journal of Pediatrics, 124(4), 513-519. https://doi.org/10.1016/S00223476(05)83127-0

Hogan, A. M., Pit-Ten Cate, I. M., VarghaKhadem, F., Prengler, M., \& Kirkham, F. J. (2006). Physiological correlates of intellectual function in children with sickle cell disease: Hypoxaemia, hyperaemia and brain infarction. Developmental Science, 9(4), 379-387. https://doi.org/10.1111/j.14677687.2006.00503.x

Kassebaum, N. J., Jasrasaria, R., Naghavi, M., Wulf, S. K., Johns, N., Lozano, R., Regan, M., Weatherall, D., Chou, D. P., Eisele, T. P., Flaxman, S. R., Pullan, R. L., Brooker, S. J., \& Murray, C. J. L. (2015). Plenary Paper RED CELLS , IRON , AND ERYTHROPOIESIS A systematic analysis of global anemia burden from 1990 to 2010. Blood Journal, 123(5), 615-625. https://doi.org/10.1182/blood-2013-06508325.The

Khan, J. R., Awan, N., \& Misu, F. (2016). Determinants of anemia among 6-59 months aged children in Bangladesh: Evidence from nationally representative data. BMC Pediatrics, 16(1), 1-12. https://doi.org/10.1186/s12887-015-0536-z

Khanam, R., Nghiem, H. S., \& Rahman, M. M. (2011). The impact of childhood malnutrition on schooling: Evidence from
Bangladesh. Journal of Biosocial Science, 43(4), 437-451. https://doi.org/10.1017/S00219320110001 49

Lozoff, B. (2007). Iron deficiency and child development. Food and Nutrition Bulletin, 28(4 SUPPL.), 560-571. https://doi.org/10.1177/15648265070284s4 09

Mohammed, S. H., Larijani, B., \& Esmaillzadeh, A. (2019). Concurrent anemia and stunting in young children: Prevalence, dietary and non-dietary associated factors. Nutrition Journal, $\quad 18(1), \quad 1-10$. https://doi.org/10.1186/s12937-019-0436-4

Murtaza, S. F., Gan, W. Y., Sulaiman, N., Shariff, Z. M., \& Ismail, S. I. F. (2019). Sociodemographic, nutritional, and environmental factors are associated with cognitive performance among Orang Asli children in Malaysia. PLoS ONE, 14(7), 116.

https://doi.org/10.1371/journal.pone.02198 41

Ngure, F. M., Reid, B. M., Humphrey, J. H., Mbuya, M. N., Pelto, G., \& Stoltzfus, R. J. (2014). Water, sanitation, and hygiene (WASH), environmental enteropathy, nutrition, and early child development: Making the links. Annals of the New York Academy of Sciences, 1308(1), 118-128. https://doi.org/10.1111/nyas.12330

Rahman, M. S., Mushfiquee, M., Masud, M. S., \& Howlader, T. (2019). Association between malnutrition and anemia in underfive children and women of reproductive age: Evidence from Bangladesh demographic and Health Survey 2011. PLoS ONE, 14(7), 1-19. https://doi.org/10.1371/journal.pone.02191 70

Shafir, T., Angulo-Barroso, R., Calatroni, A., Jimenez, E., \& Lozoff, B. (2006). Effects of iron deficiency in infancy on patterns of motor development over time. Human Movement Science, 25(6), 821-838. https://doi.org/10.1016/j.humov.2006.06.0 06

Waugh, E. J., Polivy, J., Ridout, R., \& Hawker, G. A. (2007). A prospective investigation of the relations among cognitive dietary 
restraint, subclinical ovulatory disturbances, physical activity, and bone mass in healthy young women. American Journal of Clinical Nutrition, 86(6), 17911801.

https://doi.org/10.1093/ajcn/86.6.1791

Baker, R. D., Greer, F. R., Bhatia, J. J. S., Abrams, S. A., Daniels, S. R., Schneider, M. B., Silverstein, J., Stettler, N., Thomas, D. W., Grummer-Strawn, L., Hubbard, V. S., Marchand, V., Silverman, B. M., Soto, V., \& Burrowes, D. L. (2010). Clinical report - Diagnosis and prevention of iron deficiency and iron-deficiency anemia in infants and young children (0-3 years of age). Pediatrics, 126(5), 1040-1050. https://doi.org/10.1542/peds.2010-2576

Faleiros, F. T. V., da Silva, V. N., de Assis Carvalho, M., \& Machado, N. C. (2016). Intake, bioavailability, and absorption of iron in infants aged 6 to 36 months: an observational study in a Brazilian Well Child Clinic. Nutrire, 41(1). https://doi.org/10.1186/s41110-016-0011-0

Gropper, Sareen S. Smith, J. L. (2013). Essential trace and Ultratrace Minerals. In Advanced Nutrion in Human.

Hassan, T. H., Badr, M. A., Karam, N. A., Zkaria, M., El Saadany, H. F., Rahman, D. M. A., Shahbah, D. A., Al Morshedy, S. M., Fathy, M., Hosni Esh, A. M., \& Selim, A. M. (2016). Impact of iron deficiency anemia on the function of the immune system in children. Medicine (United States), 95(47), 1-5. https://doi.org/10.1097/MD.000000000000 5395

Islam, G. M. R. (2020). Association of Socioeconomic Status With Childhood Anemia Among Infant, Toddler, and Preschool Children in Bangladesh. Value in Health Regional Issues, 21, 141-148. https://doi.org/10.1016/j.vhri.2019.09.008

Jayaweera, J. A. A. S., Reyes, M., \& Joseph, A. (2019). Childhood iron deficiency anemia leads to recurrent respiratory tract infections and gastroenteritis. Scientific Reports, 9(1), 1-9. https://doi.org/10.1038/s41598-019-49122$\mathrm{z}$

Lozoff, B. (2007). Iron deficiency and child development. Food and Nutrition Bulletin, 28(4 SUPPL.), 560-571. https://doi.org/10.1177/15648265070284s4 09

Murtaza, S. F., Gan, W. Y., Sulaiman, N., Shariff, Z. M., \& Ismail, S. I. F. (2019). Sociodemographic, nutritional, and environmental factors are associated with cognitive performance among Orang Asli children in Malaysia. PLoS ONE, 14(7), 116.

https://doi.org/10.1371/journal.pone.02198 41

Perez, Y., Presti, K., Eden, A. N., \& Sandoval, C. (2018). Iron-deficiency anemia during childhood. Anemia in the Young and Old: Diagnosis and Management, 81-93. https://doi.org/10.1007/978-3-319-96487$4 \_5$

Pusponegoro, H. D. (2012). Suplementasi besi untuk anak. Pediatric Outpatients, 21-23.

Rahman, M. S., Mushfiquee, M., Masud, M. S., \& Howlader, T. (2019). Association between malnutrition and anemia in underfive children and women of reproductive age: Evidence from Bangladesh demographic and Health Survey 2011. PLoS ONE, 14(7), 1-19. https://doi.org/10.1371/journal.pone.02191 70

Shafir, T., Angulo-Barroso, R., Calatroni, A., Jimenez, E., \& Lozoff, B. (2006). Effects of iron deficiency in infancy on patterns of motor development over time. Human Movement Science, 25(6), 821-838. https://doi.org/10.1016/j.humov.2006.06.0 06

Soyano A \& Gómez M. (1999). Role of iron in immunity and its relation with infections. Arch Latinoam Nutr., 3(2), 40s-46s.

Waugh, E. J., Polivy, J., Ridout, R., \& Hawker, G. A. (2007). A prospective investigation of the relations among cognitive dietary restraint, subclinical ovulatory disturbances, physical activity, and bone mass in healthy young women. American Journal of Clinical Nutrition, 86(6), 17911801. https://doi.org/10.1093/ajcn/86.6.1791

WHO. (2015). The global prevalence of anaemia in 2011. Who, 1-48. 